\title{
DATADELING I MEDGANG OG MODGANG
}

\author{
Refleksioner over et kollektivt feltarbejde
}

\section{LINE VESTERGÅRD OG LIV GUDMUNDSEN}

Solen brænder, og støv hvirvler forbi bussens åbne vinduer, mens overdøvende kenyansk rapmusik strømmer ud af højtalerne en tidlig mandag morgen. Da en stor rundkørsel kommer til syne, maser vi os forbi de mange svedige mænd hen mod døren forrest $\mathrm{i}$ bussen. Vi når lige at hoppe af bussen, inden den forsvinder i en støvsky.

Vi fortsætter til fods langs en trafikeret vej forbi de mange boder, der sælger alt fra kyllinger og mango til brugte sko og køkkenudstyr. Mens vi går, fortæller Liv, at hun føler sig godt tilpas hjemme hos Diana. ${ }^{1}$ De hygger sig, selvom de ofte taler om de voldelige overgreb, Diana har været udsat for. Liv fortæller, at Diana tit viser romantiske sms'er fra andre end sin mand, men at hun ikke har spurgt så meget ind til deres forhold. Liv trækker sin notesbog op af skuldertasken og slår op på siden med analytiske temaer og spørgsmål, som vi sammen har lavet. Line foreslår, at vi skal tilføje nogle spørgsmål om kvindernes relationer til mænd, selvom det ikke er vores fokus. Hun har også oplevet, at kvinderne taler meget om mænd, og tilføjer, at det kan være interessant at spørge, hvornår en mand er en god ægtemand.

Mens vi snakker, krydser vi en bro, der fører os over Nairobi River. Da vi drejer til venstre ad en smal jordsti, forsvinder trafikstøjen, og betonbygningerne bliver afløst af små huse lavet af ler eller zinkplader - mange med en vakkelvorn førstesal. Husene ligger tæt, og slummen virker som en rustfarvet labyrint fyldt med vasketøj, legende børn og høns. Det minder nærmest om en lille landsby, selvom vi befinder os i millionbyen Nairobi. Inden vi skilles, siger Line, at hun håber, at hun ikke skal vaske tøj i dag. Hun har fået ondt i ryggen af at stå foroverbøjet over vaskebaljerne i flere timer. Liv spørger ind til det, da hun endnu ikke har prøvet det. Vi aftaler at mødes ved Mama Hawas lille madbiks klokken 12 og fortsætter hver for sig ned ad to forskellige stier.

\section{Et kollektivt feltarbejde}

Denne morgen er blot en af utallige under vores feltarbejde $\mathrm{i}$ de to kenyanske slumområder Kinyago og Kanuku i efteråret 2015, hvor vi valgte at foretage 
vores feltarbejde sammen. I dag bliver feltstudier i stadig større grad udført i samarbejde mellem to eller flere antropologer, og der findes flere klassiske eksempler på (ægte)par, der tager sammen på feltarbejde (Whyte \& Whyte 1989; Comaroff \& Comaroff 1999; DeWalt \& DeWalt 2011; Lien \& Law 2013). Disse har især bidraget med refleksioner over, hvordan mandlige og kvindelige antropologer får forskellig adgang til felten og kan bidrage med forskellige perspektiver. Herudover er der også større kollektive forskningsprojekter, hvor flere antropologer har arbejdet sammen under kortere feltarbejder (Strathern 1981; Rubow et al. 2017). Denne artikel bidrager ligeledes til antropologisk metode, hvor vi bruger os selv som empiriske eksempler til at reflektere over potentialer og faldgrupper ved samarbejde.

Vi argumenterer for, at det kollektive feltarbejde påvirker forståelsen og genereringen af data og herved den etnografiske analyse. Samarbejde medvirker til, at data får et eksplicit udtryk, og giver mulighed for at udarbejde analyser med forskellige perspektiver og en stor mængde data på kort tid. Vi fremhæver vigtigheden af kritisk stillingtagen til, hvordan samspillet mellem data, metode og analyse bliver påvirket af at være to i felten. Artiklen tager afsæt $\mathrm{i}$ vores erfaringer fra et fem måneders feltarbejde i slummen i Nairobi, Kenya. Beboerne omtalte områderne som slummen eller kijiji (landsby), hvilket kan få felten til at virke geografisk afgrænset. Dog var vores feltarbejde ikke formet af faste grænser, men snarere afhængigt af sociale relationer, både vores informanters og vores egne (se Coleman \& Collins 2006).

Den første måned af vores feltarbejde havde vi uformelle samtaler med omkring 80 kvinder og valgte ni ud, der alle talte godt engelsk, havde tid og viste interesse for projektet. Vi fordelte disse kvinder imellem os efter personlig kemi, og de resterende måneder brugte vi hovedsageligt tid med dem hver for sig. For at sikre en fælles retning, sparring, udvikling af metoder og for at bibeholde motivationen fandt vi det vigtigt konstant at dele vores indsamlede data. Samarbejdet begyndte et halvt år forinden, hvor vi sammen havde planlagt at lave et fænomenologisk projekt for at forstå kvinders følelse af utryghed og normalisering af vold. Vi havde en forventning om, at vi selv ville erfare utryghed og herved bedre være i stand til at forstå kvinders umiddelbare og førrefleksive erfaringer med utryghed. Vi havde fra tidligere fælles projekter fundet ud af, at delingen af vores oplevelser og erfaringer kunne give nye indsigter, da vi ofte havde forskellige perspektiver og tilgange, hvilket optimerede vores arbejdsproces.

Efter kort tid i felten opdagede vi, at til trods for ekstrem fattigdom, udbredt kriminalitet og konstante trusler om vold var der andre sociale aspekter, der fyldte mere end utryghed i kvindernes hverdag. Særligt relationer til mænd og forestillinger om ægteskab definerede deres samtaler og syn på verden. Vi var enige om, at vi ville forsøge at lade felten tale til os snarere end at følge vores 
første antagelser og personlige interesser, hvorfor vi ændrede fokus under feltarbejdet. Vores fælles datasæt med forskellige perspektiver gav os mulighed for at teoretisere et helt nyt fænomen fra flere forskellige vinkler, nemlig come-westay-ægteskabet. Come-we-stay-ægteskabet er et uformelt, ustabilt og papirløst forhold, hvor parret efter at have boet sammen seks måneder kan kalde sig gift. Det giver en løsning på socioøkonomiske transformationer såsom fattigdom, urbanisering og arbejdsløshed, der ellers gør ægteskab umuligt i slummen. Vores analyse beskriver det nye fænomen som en social institution tæt forbundet med slægtskabsstrukturer, økonomi, kønsrelationer og magtforhold. En så bred analyse krævede forskelligartede data, hvilket vi fik gennem en bred informantgruppe med forskellig civilstatus samt gennem vores forskellige perspektiver og tilgange. I lyset heraf viser vi i denne artikel den medgang og modgang, vi erfarede under det kollektive feltarbejde, og hvordan samarbejde kan åbne for en analytisk og teoretisk kreativitet.

Næste afsnit beskriver, hvordan vi løbende delte data, og hvordan denne deling gav os en forståelse af data som både håndgribelige og abstrakte og som kultiverede og socialt produceret. Ud fra dette viser vi, hvordan fcelles erfaringsrum muliggør deling af data, og hvordan data bliver påvirket af samarbejde. Efterfølgende illustrerer vi, hvordan det at være to i felten kan bringe nye indsigter $i$ forhold til positionering. Afslutningsvis diskuterer vi, hvordan deling af data åbner for nye etiske problemstillinger og samtidig hjælper til at håndtere disse.

\section{Data som kultiverede, sanselige og sociale}

Under feltarbejdet deltog vi hver for sig i kvindernes hverdag og brugte dage, uger og måneder med dem. Vi talte med dem om deres glæder og sorger, deres tanker om fortiden og håb for fremtiden. Vi deltog i deres dagligdag med tøjvask, madlavning og børnepasning, og den viden og de erfaringer, vi opnåede herfra, delte vi med hinanden. Vores samarbejde inkluderede blandt andet diskussioner af faglitteratur, udformning af interviewguides, transskribering af hinandens interviews, diskussioner af emiske termer, evaluering af forskellige metoder og analyse af feltnoter. Denne deling af data blev fremmet af, at vi boede sammen og tilbragte det meste af vores tid uden for felten sammen.

En sådan deling af data påvirker vores opfattelse af, hvad data er. Vi forstår data som flere forskellige former for empirisk materiale, for eksempel feltnoter, observationer, udkast til fortolkninger, avisartikler og fotografier (jf. Hastrup et al. 2011). Under samarbejde inkluderer denne forståelse af data også de diskussioner, vi har med hinanden om metoder og analytiske pointer, da disse øger vores indsigt $\mathrm{i}$ og forståelse af felten. 
Artiklen bygger således på den konkrete datamængde, vi producerede, som består af 500 sider computerskrevne feltnoter, mere end 600 billeder, 20 transskriberede interviews, slægtskabsdiagrammer over syv familier og fem tegninger over området. Herudover er der alt det, der ikke nødvendigvis er nedskrevet, for eksempel utallige følelser og oplevelser. Denne datamængde skal ikke forstås som en favorisering af kvantitet, men vise samspillet mellem den store mængde data, der genereres under det kollektive feltarbejde, og den kvalitative dybdegående analyse.

Som den indledende vignet viser, udvekslede vi også sanselige erfaringer her smerter i ryggen og det at føle sig som en del af felten. Andre gange kunne det være frustrationer over at føle sig malplaceret, akavet tavshed eller noget helt tredje. Således delte vi en kropslig erfaring og etnografisk nedsænkning i felten. Line Dalsgård argumenterer for, at følelser, sanseindtryk og kropslig kunnen bliver blandet med intellektuel viden og erfaring, der ikke altid lader sig udtrykke i ord (Dalsgård 2003:330). Ved at være to på feltarbejde erfarede vi dog, at disse former for data ofte bliver italesat og vist, hvilket artiklen ligeledes illustrerer. Med denne baggrund forstår vi også data som sanselige.

Samtidig ser vi data som kultiverede, hvilket afspejles i vores feltnoter, der indeholder en udvælgelse af, hvad der nedskrives, og hvad der undlades. Det afspejles i, hvad kvinderne vælger at fortælle eller ikke fortælle, og det afspejles i, hvad vi deler eller ikke deler med hinanden. Data er altid fortolkede, gjort meningsfulde, kombineret med anden viden eller opsummeret af dem, vi interagerer med, og af os selv i forsøget på at forstå den sociale virkelighed. Som Clifford Geertz siger „det, vi kalder data, er i virkeligheden vores egen konstruktion af andres konstruktioner af det, de og deres landsmænd foretager sig“"2 (Geertz 1973:9). Med denne forståelse bevæger vi os væk fra en forståelse af, at data kan være ,rå“, til en opfattelse af data som altid bearbejdede (jf. Møhl 2003:177; Hastrup 2004). Vi forstår altså data som foranderlige, kultiverede, sanselige og sociale.

Vores forståelse og genererede data er således formet af vores samarbejde. I næste afsnit undersøger vi, hvordan deling af data kommer til udtryk i vores samarbejde, og hvilke analytiske muligheder det medfører.

\section{Dataopdagelser i fælles erfaringsrum}

Da klokken bliver lidt over 12, mødes vi hos Mama Hawa. Hendes lille bod består af et halvtag, et par presenninger og en lille kulovn, hvor hun sælger frisklavede chepatis (afrikanske fladbrød). Mens Mama Hawa laver vores frokost, indvier vi hinanden i formiddagens begivenheder. Vi holder hinanden opdateret om vores planer for dagen. Line fortæller, at hun vil se om Winnie, der er frisør, er hjemme, og at hun vil hjælpe hende med at flette hår. Liv spørger ind til, hvordan det plejer 
at foregå, når der bliver flettet hår - hvor sidder Line, hvor meget må hun hjælpe, snakker hun med Winnie imens, eller snakker Winnie med kunden? Liv spørger også, hvordan Line har det, når hun er sammen med Winnie - føler hun sig godt tilpas, og kan hun være sig selv?

Idet vi havde hver vores gruppe af informanter, oplevede vi, at det var nødvendigt at skabe analytiske rutiner, der gav plads til deling af data. Vi delte data i mange forskellige situationer - når vi mødtes til frokost, når vi gik til og fra slummen, og når vi om aften skrev feltnoter i vores fælles lejlighed. Cathrine Hasses forståelse af feltarbejdet som en læreproces og dennes indvirkning på rummet hjælper os til at begrebsliggøre de rum for deling af data, vi etablerede. Hasses forståelse gør det ligeledes lettere for os at bruge de data, vi får gennem vores fælles samtaler og diskussioner, da vi herved kan strukturere og rutinepræge vores datadeling. Hasse understreger, at sociale verdener udgøres af mennesker, der med udgangspunkt i delte kulturelle erfaringer har et fælles kendskab til, hvordan det fysiske rum kan identificeres. Ved det fysiske rum forstås ikke alene de fysiske genstande. Også ord og mennesker manifesterer sig som konkret stof i det fysiske rum, der omgiver os. Læring om den verden, folk erfarer og omformer, finder sted i en social praksis, der er forankret i fysiske rum (Hasse 2002, 2003). Vi forstår rum på samme måde, men hvor Hasse fokuserer på det rum, antropolog og informant deler, ser vi på de rum, vi skaber mellem os til at dele data, og foreslår begrebet falles erfaringsrum.

Fælles erfaringsrum definerer vi som de fysiske rum, hvori vi deler vores erfaringer og andre former for data med hinanden. Disse rum har vi et fælles kendskab til, og vores sociale praksisser og analytiske rutiner er forankret i disse rum, som når vi spiser frokost hos Mama Hawa eller deler analytiske spørgsmål på vej til slummen. Vi ser altså disse rum som medvirkende til genereringen af data. Disse fælles erfaringsrum bliver opretholdt og reproduceret gennem daglige interaktioner og uformelle samtaler, der giver plads til gentagende refleksion og analytisk skærpelse.

De fælles erfaringsrum indeholder metodiske, analytiske, praktiske og etiske aspekter af det, der er fælles. Da Line for eksempel en aften i vores fælles lejlighed skal vaske tøj, viser hun Liv, hvordan kvinderne i slummen vasker deres tøj. Her er der tale om et praktisk aspekt i form af tøjvask og ligeledes et metodisk aspekt tilegnet gennem deltagerobservation, hvilket åbner op for en analytisk samtale. Således skal de forskellige aspekter af det fælles forstås flydende og ses som noget, der udtrykkes forskelligt alt efter situationen.

I de fælles erfaringsrum søgte vi, udover at dele data fra felten, også at få indsigt $i$ den andens dagligdag, sociale relationer og tankemønstre. Ved feltarbejdet forstås, at antropologen placerer sig i det, der undersøges, deltager i og observe- 
rer den hverdag, som folk lever i (Hastrup et al. 2011:7). Det, at vi var to af sted og kontinuerligt indgik i fælles erfaringsrum, gjorde, at vi udover at være på feltarbejde $\mathrm{i}$ kvindernes verdener ligeledes var på feltarbejde $\mathrm{i}$ den andens feltarbejde, da vi også undersøgte, deltog i og observerede hinandens hverdag. Vi fandt dette nødvendigt for at forstå hinandens data, da det gav kendskab til, hvordan den anden identificerede de fysisk rum og sociale aktiviteter. Dette bygger på en forståelse af forskellighed inspireret af Donna Haraway. Haraway beskriver, hvordan vi bebor verden forskelligt, og at ens evne til at erkende forskelle, for eksempel andres viden om felten, kan kultivere en modtagelighed og sensitivitet, der helt konkret kan udvikle ens faglige tilgang (Haraway 2016). Tillid og gensidig forpligtelse over for hinanden kan på denne måde komme til at fungere befordrende for deling af data og er dermed afgørende for den analytiske proces.

At være på feltarbejde i den andens feltarbejde og kontinuerligt dele personlige tanker og følelser kan dog også være krævende. Hvis parterne ikke formår at give plads til hinandens forskelligheder, kan det medføre store vanskeligheder for samarbejdet. Forskellige arbejdsrutiner kan være hæmmende for projektet, eksempelvis hvis parterne har forskellige holdninger til tidsforbrug i felten eller arbejdsgang. De fælles erfaringsrum skal derfor tilpasses de forskellige arbejdsrutiner på en måde, der er gavnlig for alle parter. Selvom vi fra tidligere samarbejde vidste, at vores arbejdsrutiner var forenelige, fandt vi det vigtigt løbende at afstemme vores forventninger til arbejdsbyrde, arbejdsfordeling og personlige behov samt at udarbejde en samarbejdskontrakt. De gentagende refleksioner og den analytiske skærpelse kom altså ikke dumpende, men var et arbejde, vi gjorde med hinanden.

Den løbende forventningsafstemning, der fandt sted i de fælles erfaringsrum og vores samarbejde generelt, bevirkede, at vores data fik et mere eksplicit udtryk, blandt andet fordi vi kontinuerligt forklarede hinanden, hvorfor vi traf de metodiske valg, vi gjorde. Det var også tydeligt i vores feltnoter, der var skrevet med øje for, at de skulle læses af en anden. Eksempelvis lavede vi ofte små ordforklaringer til ord på swahili, hvis vi ikke var sikre på, om den anden kendte ordet. Dette gav os mulighed for at sammenligne vores oversættelser og herved betydningen og brugen af ordene. Denne eksplicitet har paralleller til nogle af de refleksioner, deltagerne i forskningsprojektet Utopia på Københavns Universitet har gjort sig om etnografisk samarbejde (www.soc.ku.dk/instituttet/arrangementer/ utopia-14--en-feltstudiedag-om-utopier-i-det-urbane-rum/). Utopia var en feltstudiedag, hvor 100 deltagere i mindre grupper indsamlede materiale om utopier i det urbane rum i København. Hvor Utopia var et kort kollektivt feltarbejde i stor skala, udført på få dage af mange mennesker flere forskellige steder, er vores feltarbejde et længerevarende kollektivt feltarbejde i lille skala. Fælles for de to 
projekter er dog en eksplicit refleksion over de analytiske og metodiske rutiner. Cecilie Rubow og andre beskriver, at brugen af gruppevise observationer og analyser institutionaliserer et krav om gensidig „redegørbarhed“ i feltnotepraksis, og at ambitionen om et fælles materiale tilskynder til en fælles refleksion over rutiner, der ellers kan have tendens til at forblive usagte (Rubow et al. 2017:45). Denne pointe lægger dog også op til en faldgrube i det kollektive feltarbejde, da det kan være svært at eksplicitere abstrakte analytiske tanker. Komplekse idéer kan blive afskrevet for hurtigt, hvis man ikke formår at forklare dem, hvorved den produktive indforståethed kan gå tabt. Her erfarede vi, at arbejdsrutiner igen var vigtige for at imødekomme denne udfordring, da nogle får stort udbytte af interne tankestrømme, mens andre har behov for en konstant idéudveksling. For os var den tvungne eksplicitet hovedsageligt fremmende for den analytiske proces, fordi vi var nødt til at forklare og tydeliggøre vores overvejelser undervejs. Den eksplicitet, der fandt sted i de fælles erfaringsrum, anser vi således som essentiel for deling af data og indfangelse af de analytiske perspektiver, der udsprang heraf.

Vi fandt også, at et tidsligt aspekt spillede ind på en særlig måde, når data blev ekspliciteret i de fælles erfaringsrum. Eksempelvis lærte Line at flette hår af Winnie, og en aften i vores fælles hjem viste hun Liv det. Da Liv nogle dage senere var med til at flette hår, kendte Liv allerede teknikken og stillede derfor ikke spørgsmål om dette, men fik i stedet oplysninger om hårs symbolske betydning. Kirsten Hastrup argumenterer for, at antropologens væren i felten er en sammensmeltning af praktiske færdigheder og evnen til at stille meningsfulde spørgsmål. En evne, der opstår over tid og tillader antropologen at få anerkendelse fra sine informanter, hvilket åbner for samtaler om deres verdenssyn snarere end blot overfladisk information (Hastrup 2004:466). Vi er enige med Hastrup i, at data indsamlet over en længere periode er værdifulde, særligt i relationsdannelsen. Dog argumenterer vi for, at det at være to i felten kan give mulighed for at indsamle dybdegående data hurtigere, end hvis antropologen er alene af sted, da vi, som eksemplet viser, har mulighed for trække på hinandens erfaringer og gå fra overfladisk information til dybdegående erfaringer. Dette finder vi særligt værdifuldt $i$ en tid, hvor tendensen går i retning af stadig kortere feltarbejder både på universiteterne og i arbejdsmæssigt regi. Imidlertid er det vigtigt at understrege, at selve samarbejdet også er tidskrævende, da det tager tid at dele data, etablere fælles erfaringsrum og diskutere forskellige perspektiver.

Udvekslingen i de fælles erfaringsrum gav os også mulighed for eksplicit at reflektere over vores positioneringer. Derfor undersøger vi i næste afsnit, hvordan det kollektive feltarbejde har indflydelse på positionering, og hvilke faldgrupper der er forbundet hermed. 


\section{Forskellige hænder - forskellige roller}

Line går over for at besøge Winnie. Hun har ikke nogen kunder, så i dag går med huslige gøremål. Først skal der vaskes tøj. Inden Line og Winnie går i gang, tager Winnie Lines hænder og vender dem rundt for at se på håndfladerne. Hun peger på Lines hårde hud, som er resultatet af personlig træning, og lyser op i et smil og udbryder, at Line godt kan arbejde. Derefter henter de store dunke med vand og tre vaskebaljer fyldt med tøj. Mens de vasker tøjet i hånden, drejes samtalen ind på den fysiske udholdenhed, det kræver at stå foroverbøjet og vaske tøj i flere timer. Line spørger Winnie, om hun ikke holder pauser, hvortil Winnie svarer, at det gør hun kun, hvis hun får en kunde, der skal have flettet hår, da det er vigtigere at tjene penge.

Samtidig sidder Liv i Faiths lille hjem, hvor der kun er plads til en lille sofa og en enkeltmandsseng. Mens de taler, kommer Liv til at spilde varm te over sig selv og sofaen. Faith tørrer straks op med en gammel T-shirt. Hun tørrer også Livs fingre, præcis som Liv har set hende gøre på sin 5 -årige datter. Faith tager undersøgende fat om Livs hænder og siger: 'Du har så bløde hænder, du har aldrig arbejdet i dit liv.' Liv spørger ind til, hvornår Faith begyndte at arbejde, og hun fortæller om en barndom fyldt med vold, sult og hårdt arbejde. Mens Liv er sammen med Faith, får hun en sms fra Line, og Faith fortæller, at hun er bange for Line og synes, at hun virker barsk. Liv spørger ind til hvorfor, og Faith henviser til Lines rette gang og siger, at hun ser stærk ud og ikke smiler så meget. Sidst på eftermiddagen siger de farvel, og Faith følger Liv ud af det lille hjem.

Ovenstående illustrerer, at vores samarbejde gav indsigt i vores positionering, vores relationer til kvinderne og mulighed for at reflektere over disse. Dette eksempel viser blot to af de mange forskellige positioneringer, vi blev tildelt under feltarbejdet. Hasse argumenterer i sin tekst om positioneret deltagerobservation for, at feltets deltagere tildeler antropologen positioneringer, hvad enten antropologen er bevidst om det eller ej (Hasse 2000:43). Ovenstående eksempel viser netop, hvordan Line som udgangspunkt ikke var bevidst om sin positionering i felten som barsk, men blev opmærksom på det gennem vores samarbejde. Denne viden ville Line formentlig aldrig have fået, hvis hun var alene på feltarbejde. Deltagerne i felten tildeler altså antropologen en position, som antropologen er ubevidst om. I forlængelse af ovenstående argumenterer vi for, at antropologen kan blive bevidst om disse i det kollektive feltarbejde. I dette eksempel giver det Line mulighed for bedre at forstå sin positionering og betydningen af den for datagenereringen. Da Line blev positioneret som en, der godt kan arbejde, og som barsk, brugte hun denne viden til at lave deltagerobservation i fysisk hårde aktiviteter. I udførelsen af disse aktiviteter kom samtalerne ofte til at omhandle, hvordan kvinderne tjente penge, deres økonomiske situation og den udbredte korruption i området. Modsat blev Liv positioneret som mere sårbar, hvilket især gav mulighed for personlige samtaler om voldtægt og overgreb - situationer, 
hvor kvinderne følte sig sårbare. Derfor er Livs data i højere grad fokuseret på kvindernes erfaringer med vold, sorger og eksistentielle kriser forbundet med ekstrem fattigdom. Herved giver forskellige positioner forskellige data, hvilket særligt blev klart, når vi sammenlignede vores noter, metoder og overvejelser. Denne arbejdsdeling var ikke planlagt på forhånd, men opstod løbende som følge af vores forskellige positioneringer og relationer til kvinderne. Vi fandt dette fremmende for samarbejdet, da vi herved kunne bidrage med forskellige indsigter. Kathleen og Billie DeWalt beskriver forskellige interesser, viden og færdigheder som en styrke, da etnografens personlige interesser bevirker, at data får forskellige perspektiver, hvilket giver en mere detaljeret forståelse af felten (DeWalt \& DeWalt 2011:102). Hvordan vi blev positioneret, og hvilke perspektiver vi fik indsigt $i$, ændredes naturligvis under feltarbejdet, $i$ takt med at vi lærte felten bedre at kende, og afhængigt af hvilke kvinder vi tilbragte tid med. I forlængelse heraf forstår vi positionering og data som i kontinuerlig forandring og altid situeret (jf. Haraway 1988).

Data med mange forskellige perspektiver er også en stor udfordring, da det kan skabe uenigheder om retning og prioritering af forskellige temaer. For at overkomme disse vanskeligheder udarbejdede vi forskellige tematiske spørgsmål og fælles interviewguides. Disse metodiske tiltag kombineret med løbende samtaler om projektets retning hjalp os til at bevare en fælles forståelse, afgrænse det analytiske fokus og skabe en ramme for projektet.

Ved at være to på feltarbejde erfarede vi, at nogle af vores positioneringer blev forstærket. Dette kom særligt til udtryk, ved at kvinderne forsøgte at differentiere mellem os via forskellige roller. Vi oplevede eksempelvis, at Livs position som sårbar og Lines som barsk blev fastholdt grundet denne differentiering og således var en konsekvens af at være to på feltarbejde. Det gjorde os opmærksomme på at spørge ind til emner, vi ikke selv havde tænkt over, men som vi først erfarede i delingen af data med hinanden. Ydermere oplevede vi, at vores forskellige positioneringer gav indsigt i forskellige data om de samme kvinder, ved at en af os indgik i en fortrolig relation til den pågældende informant, og den anden indtog en mere distanceret rolle. Eksempelvis fortalte Faith meget intime detaljer om oplevelser til Liv, mens hun i samtaler med Line om samme oplevelser fokuserede mere på eksterne forhold og overordnede detaljer. Vores forskellige positionering spillede en afgørende rolle for data. Det, at vi var to på feltarbejde, påvirkede kvinderne og det, de fortalte os. I forlængelse heraf diskuterer vi i næste afsnit, hvordan vores kollektive feltarbejde spillede ind i forhold til spørgsmål om samtykke, loyalitet og etik. 


\section{Fælles om etiske udfordringer}

Liv følger den lille jordvej, der er blevet mudret af dryppende vasketøj, som hænger overalt mellem de små huse. Hun hopper over den åbne rendesten fyldt med affald, der løber mellem husene i slummen. Hun banker stille på en lav trædør til et lille lerhus. Både Line og Rachel ser op og smiler, da Liv stikker hovedet ind i det lille rum. Rachel står bøjet over en gryde, hvor vandet er ved at koge. Rachel spørger, hvad Liv har lavet i løbet af dagen, og hvad vi skal i aften. Liv fortæller, at vi skal renskrive noter og snakke om, hvad vi hver især har oplevet. Line pakker sin notesbog sammen, og Rachel siger tak for i dag.

Vi krydser Nairobi River og går langs den støvede vej, da Line fortæller, at Rachel er gravid, og at Rachel har bedt hende ikke fortælle det til nogen i slummen. Hun er bange for, at hendes far vil blive rasende og smide hende ud, hvis han finder ud af det. Der bliver stille et øjeblik, og vi overvejer kort, om det er etisk forsvarligt, at Line fortæller hemmeligheden videre. Imidlertid er Line sikker på, at Rachel godt ved, at vi deler alt. Dette bliver også bekræftet senere på ugen, hvor Rachel spørger, hvad Liv sagde til nyheden om hendes graviditet.

Som ovenstående eksempel viser, kan det at være to i felten og dele data også åbne for nye problemstillinger. Som antropologer er vi opmærksomme på kontekstuelle magtforskelle, begrænsninger, interesser og forventninger, der er karakteristiske for alle sociale relationer. Med en sådan tilgang er misforståelser, konflikter og nødvendigheden af at foretage valg uundgåelige, og etiske dilemmaer vil nødvendigvis opstå både i felten og i samarbejdet (jf. Møhl \& Simonsen 2018:121). Gennem vores fælles erfaringsrum blev vi opmærksomme på forskellige etiske overvejelser, blandt andet om samtykke til at dele personlige informationer. Perle Møhl og Anja Simonsen har udført feltarbejde hver for sig to forskellige steder, men de samarbejder i et fælles forskningsprojekt, hvor de sætter spørgsmålstegn ved, om man kan dele viden uden at give køb på de tillidsforhold, man som antropolog har til deltagerne i sin felt (op.cit.116). Det skal her siges, at begge deres felter i høj grad er præget af politisk spænding, hvilket er i kontrast til vores felt. I eksemplet ovenfor deler Line en fortrolig viden med Liv, hvilket kan betragtes som illoyalt og etisk ukorrekt, idet det strider mod Rachels ønske. For at undgå at sætte vores loyalitet over styr mindede vi løbende kvinderne om formålet med vores tilstedeværelse. Dette kunne dog ikke italesættes konstant, da det ville virke upassende og bryde flowet i samtalerne (Dewalt \& DeWalt 1998:287). Vores rutine med at hente hinanden hos kvinderne mindede dem indirekte om vores formål, og at de var del af vores feltarbejde. I den ovenstående etnografiske beskrivelse bliver Rachel mindet om vores hensigt med at være i felten, da Liv kom og henter Line, og om, at vi deler de informationer, vi får. I dette eksempel var påmindelsen eksplicit, da Liv forklarede, at vi senere skulle dele data. Andre gange skete påmindelsen indirekte enten ved at tage en notesbog frem el- 
ler ved den anden feltarbejders fysiske tilstedeværelse (Dewalt \& Dewalt 2011). Kvindernes opmærksomhed på, at vi var der som forskere, og at vi indsamlede etnografiske data, blev herved fremhævet løbende gennem hele feltarbejdet, fordi vi var to i felten. Dette er i overensstemmelse med American Anthropological Associations retningslinjer, der understreger vigtigheden af informeret samtykke fra forskningsdeltagere som en proces, der bør indgå løbende under hele forskningsperioden (American Anthropological Association 2012). I forlængelse heraf argumenterer vi for, at via påmindelsen om „den anden feltarbejder“ etableredes samtykke kontinuerligt gennem hele vores kollektive feltarbejde.

For at sikre loyalitet mod hinanden og vores informanter havde vi inden feltarbejdet udformet en skriftlig samarbejdsaftale med inspiration fra American Anthropological Associations retningslinjer vedrørende adgang til og ejerskab af data. Her understreges vigtigheden af at diskutere forståelsen af samarbejdet, rettigheder og ansvarsområder med informanterne (ibid.). Aftalen foreskriver, at de indsamlede data skal deles, og at vi begge har lige rettigheder til data. Til denne aftale knytter der sig retningslinjer i forhold til den situation, data er genereret $i$. I ovenstående eksempel blev data genereret som en hemmelighed, hvorfor Liv ligeledes skulle behandle data som en hemmelighed. Grundet denne aftale med specifikke retningslinjer om, hvordan vi håndterer data og efterfølgende anonymisering, forstår vi ikke deling af hemmeligheder eller andre personlige detaljer som tillidsbrud, men snarere som et nødvendigt element i det kollektive feltarbejde for at anerkende individuelle problemstillinger. Antropologers indvirken på felten er uundgåelig, men delingen af data hjalp os til at være velovervejede i vores samtaler med kvinderne. Dette kom for eksempel til udtryk, idet Line ved at dele hemmeligheden med Liv - kunne diskutere fordele, ulemper og konsekvenser ved de efterfølgende samtaler, hun havde med Rachel om hendes graviditet, hvor Rachel søgte råd om, hvorvidt hun skulle flytte sammen med faren til barnet. Sige det til forældrene? Eller få en abort? Dette er blot et eksempel af mange, hvor vi diskuterede forskellige nuancer og reaktioner i svære situationer i samtaler med kvinderne. Herved oplevede vi, at etiske dilemmaer blev lettere at bære, fordi vi havde mulighed for at dele dem, hvorfor vi argumenterer for, at deling af data gav os en robusthed i felten.

Vi kan ikke sige, om vi oplevede flere eller færre etiske udfordringer end de, der tager alene på feltarbejde, men da vi kom hjem og delte vores erfaringer med andre studerende, var det tydeligt, at det havde været lettere for os at stå i svære situationer, netop fordi vi havde haft mulighed for at diskutere, hvordan vi navigerede bedst muligt uden negative konsekvenser for kvinderne. 


\section{Konklusion}

Inden for antropologien udspringer hele tiden nye former for samarbejde - nogle med private firmaer, andre på tværs af discipliner og igen andre mellem fagfæller. Med fokus på sidstnævnte har formålet med denne artikel været at beskrive og reflektere over nogle af de erfaringer, vi gjorde os gennem samarbejde og deling af data under vores feltarbejde i to slumområder i Nairobi, Kenya. Vores løbende deling af data gav os en forståelse af data som abstrakte, kultiverede og socialt produceret. Udover at dele feltnoter og transskriberede interviews, som er velkendte former for data i antropologien, inkluderede vi også vores indbyrdes diskussioner og samtaler som data til opnåelse af indsigt i felten og de mennesker, vi søgte at forstå. Gennem begrebet fælles erfaringsrum har vi beskrevet de rum, der blev skabt, for at deling af data løbende kunne finde sted. Efterfølgende har vi reflekteret over, hvordan vores samarbejde har indvirket på vores data og analytiske proces, og hvordan det kollektive feltarbejde både har givet medgang og modgang.

Vores samarbejde gav hovedsageligt medgang og muliggjorde en anden og bredere forståelse af kvindernes liv og come-we-stay-ægteskabet, end hvis vi havde lavet individuelt feltarbejde. Herudover gav de fælles erfaringsrum mulighed for, at vores data og den løbende analyse blev fremstillet eksplicit gennem hele projektet. Desuden oplevede vi, at det at være to på feltarbejde gav os en øget forståelse af vores tildelte positionering i felten. Vi fandt især en styrke i det at være to, når vi stod over for etiske problemstillinger, da vi havde mulighed for at diskutere konsekvenserne af vores tilstedeværelse samt inddrage forskellige perspektiver og løsningsmuligheder, når vi stod over for svære valg.

Men deling af data var også udfordrende og tidskrævende. Den store mængde data, vi indsamlede, var til tider svær at overskue, og det var udfordrende at finde et fokus, der inkluderede de forskelligartede data og vores forskellige interesser. Forskellige forventninger kan potentielt skabe konflikt, hvorfor parterne er forpligtet til at give plads til hinanden og deres forskellige data. Vi overkom disse faldgruber gennem de fælles erfaringsrum, hvori vi blandt andet forventningsafstemte, udarbejdede en samarbejdsaftale, løbende lavede evalueringer og aftalte arbejdsfordeling.

Der er utallige måder at udføre antropologiske samarbejder på, men vi håber, at vi med vores erfaringer har rejst nogle nye spørgsmål og idéer til videre diskussion. Vi håber, at antropologer, der står over for at skulle samarbejde og dele data, kan bruge vores erfaringer, undgå de faldgruber, det kollektive feltarbejde kan føre med sig, og at de vil reflektere over, hvordan deres samarbejde indvirker på deres indsamlede data og analytiske processer. ${ }^{3}$ 


\section{Noter}

1. Informanterne er anonymiseret via pseudonymer.

2. Oversættelsen er forfatternes egne.

3. Dette projekt og feltarbejde er støttet af DIGNITY Dansk Institut mod Tortur, der har givet akademisk vejledning, kontorplads og økonomisk støtte. En særlig tak til Lotte Buch Segal for den indledende idéudvikling og løbende sparring til denne artikel, og for brugbar vejledning og inspiration gennem hele kandidatforløbet.

\section{Litteratur}

American Anthropological Association

2012 Principles of Professional Responsibility. http://ethics.americananthro.org/ category/statement/.

Bundgaard, Helle

2003 Lærlingen. Den formative erfaring. I: K. Hastrup (red.): Ind i verden. En grundbog i antropologisk metode. Side 51-70. København: Hans Reitzels Forlag.

Comaroff, Jean \& John L. Comaroff

1999 Occult Economies and the Violence of Abstraction. Notes from the South African Postcolony. American Ethnologist 26:279-301.

Dalsgård, Anne Line

2003 Teksten. Kunsten at fortælle. I: K. Hastrup (red.): Ind i verden. En grundbog i antropologisk metode. Side 325-42. København: Hans Reitzels Forlag.

Dewalt, Kathleen \& Billie Dewalt

1998 Participant Observation. In: H.R. Bernard (ed.): Handbook of Methods in Cultural Anthropology. Pp. 259-300. Walnut Creek: AltaMira Press.

2011 Participant Observation. A Guide for Fieldworks. Lanham: AltaMira Press.

Geertz, Clifford

1973 The Interpretation of Cultures. Selected Essays. New York: Basic Books Inc. Publishers.

Haraway, Donna

1988 Situated Knowledges. The Science Question in Feminism and the Privilege of Partial Perspective. Feminist Studies 14:575-99.

2016 Staying with the Trouble. Making Kin in the Chthulucene. Durham: Duke University Press.

Hasse, Cathrine

2000 Overvejelser om positioneret deltagerobservation. Kvinder, Køn og Forskning 4: 39-51.

2002 Kultur i bevægelse. Fra deltagerobservation til kulturanalyse - i det fysiske rum. København: Forlaget Samfundslitteratur.

2003 Mødet. Den antropologiske læreproces. I: K. Hastrup (red.): Ind i verden. En grundbog i antropologisk metode. Side 71-92. København: Hans Reitzels Forlag.

Hastrup, Kirsten

2004 Getting it Right. Knowledge and Evidence in Anthropology. Anthropological Theory 4:455-72. 
Hastrup, Kirsten, Cecilie Rubow \& Tine Tjørnhøj-Thomsen

2011 Kulturanalyse kort fortalt. Frederiksberg: Samfundslitteratur.

Law, John \& Marianne Elisabeth Lien

2013 Slippery. Field Notes on Empirical Ontology. Sage Journals 43:363-78.

Møhl, Perle

2003 Synliggørelsen med kameraet i felten. I: K. Hastrup (red.): Ind i verden. En grundbog i antropologisk metode. Side 163-84. København: Hans Reitzels Forlag.

Rubow, Cecilie, Anders Blok, Trine Bøgkjær, Thomas Aarup Due, Ester Fritsch, Cecilie Jessen Hansen, Marianne Viftrup Hedegaard, Louise Nymann Jensen \& Mette Marie Stahl Pedersen

2017 Utopia. Kort, kollektivt feltarbejde i stor skala. Tidsskriftet Antropologi 76:37-54.

Strathern, Marilyn

1981 Kinship at the Core. An Anthropology of Elmdon, a Village in North-West Essex in the Nineteen-Sixties. Cambridge: Cambridge University Press.

Whyte, Susan \& Michael Whyte

1989 Hambas skind - mennesker, medier og ånder i Uganda. I: K. Hastrup \& K.

Ramløv (red.): Kulturanalyse - fortolkningens forløb i antropologien. Side 145-60.

København: Akademisk Forlag. 